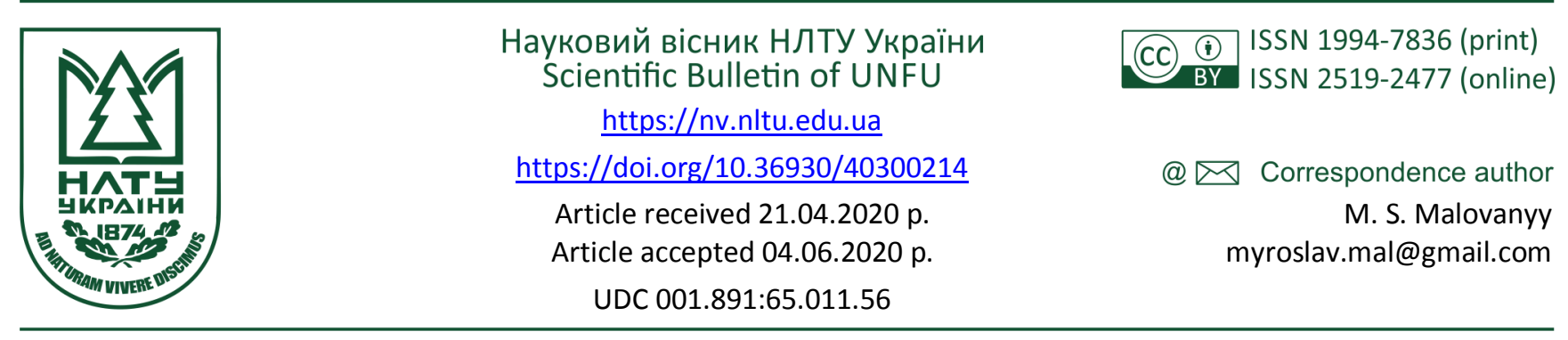

О. А. Нагурський', І. С. Тимчук', М. С. Мальований', С. Д. Синельніков², Г. В. Крилова ${ }^{1}$

${ }^{1}$ Національний університет "Львівська політехніка", м. Львів, Украӥна ${ }^{2}$ ДП "Західний експертно-технічний центр", м. Львів, Украӥна

\title{
ТЕХНОЛОГІЧНІ ОСОБЛИВОСТІ КАПСУЛЮВАННЯ ГРАНУЛЬОВАНИХ ДОБРИВ ПЛІВКОЮ НА ОСНОВІ МОДИФІКОВАНОГО ПЕТФ
}

\begin{abstract}
Проаналізовано взаємодію твердої дисперсної фази, рідкого плівкоутворювача та повітря під час капсулювання гранульованих мінеральних добрив. Показано, що на поверхні частинки відбувається передача тепла від повітря до розчину плівкоутворювача і видалення розчинника у середовище газової фази. Оцінено вплив гідродинаміки, тепло- та масообміну на процес капсулювання амонійної селітри та нітроамофоски в апараті псевдозрідженого стану плівками, які складаються 3 модифікованого поліетилентерефталату, гідролізного лігніну та цеоліту. Встановлено, що визначальним технологічним параметром процесу капсулювання $\epsilon$ швидкість повітря, за якої шар твердого матеріалу буде перебувати у стані стійкого псевдозрідження. Теоретичним методом розраховано швидкість повітря в апараті для капсулювання аміачної селітри 5,6 м/с та нітроамофоски $6,1 \mathrm{~m} / \mathrm{c}$. Проведено аналітично-експериментальні дослідження тепломасообміну під час капсулювання гранульованих добрив у апараті псевдозрідженого стану циліндричного типу періодичної дії за встановлених гідродинамічних режимів. Отримано експериментальні залежності температури повітря від висоти шару досліджуваних мінеральних добрив за витрати плівкоутворювача $1 \cdot 10^{-4} \mathrm{\kappa} / \mathrm{c}, 3 \cdot 10^{-4} \mathrm{\kappa г} / \mathrm{c}$ i $5 \cdot 10^{-4} \mathrm{\kappa} / \mathrm{c} 3$ використанням 7-канального інтелектуального перетворювача, який дав змогу одночасно фіксувати температуру в семи точках з виводом інформації на ПК. Графічним методом за кутом нахилу температурних кривих встановлено значення коефіцієнтів тепловіддачі $\alpha$ під час капсулювання аміачної селітри $135,7 \mathrm{BT} /\left(\mathrm{M}^{2} \mathrm{~K}\right)$ і нітроамофоски $118,3 \mathrm{BT} /\left(\mathrm{м}^{2} \mathrm{~K}\right)$. Для плівкоутворювального розчину, який складався із етилацетату $87 \%$ (мас), модифікованого ПЕТФ $10 \%$ (мас), гідролізного лігніну 3 \% (мас) визначено коефіцієнти масовіддачі $\beta$ під час капсулювання аміачної селітри $0,251 \mathrm{~m} / \mathrm{c}$ і нітроамофоски $0,198 \mathrm{~m} / \mathrm{c}$. На підставі отриманих коефіцієнтів масовіддачі встановлено максимальну витрату плівкоутворювача $P_{\max }\left(10^{4}\right.$ кг/с·кг добрив): аміачна селітра - 20,512, нітроамофоски - 22,857. За отриманими технологічними параметрами здійснено капсулювання досліджуваних добрив. За характером кінетичних кривих вивільнення компонентів із капсульованих частинок аміачної селітри і нітроамофоски встановлено, що за визначеними технологічними параметрами отримано мінеральні добрива із прогнозованими властивостями.
\end{abstract}

Ключові слова: капсулювання; відходи ПЕТФ; теплообмін; масообмін; мінеральні добрива.

Вступ. Капсулювання мінеральних добрив розглядають як один із важливих методів модифікування їх властивостей. Застосування капсульованих добрив зменшує непродуктивні втрати елементів живлення, що знижує забруднення довкілля залишковими агрохімікатами $[8,10,16,17]$. Екологічність капсульованих добрив грунтовно описано у науковій літературі $[4,6,9$, 14]. На ринку мінеральних добрив представлено широкий асортимент капсульованих добрив пролонгованої дії. Однак такі добрива не мають на сьогодні масового застосування у сільськогосподарському виробництві через значне зростання їх вартості. Тому актуальним $\epsilon$ дослідження з розроблення капсульованих добрив, які зможуть конкурувати поряд із традиційними у сільськогосподарському виробництві. Важливим етапом таких досліджень є визначення основних технологічних параметрів процесу нанесення покриття на поверхню гранул мінеральних добрив із застосуванням розробленої плівкоутворювача на основі відходів поліетилентерефталату (ПЕТФ).

Об'єкт дослідження - капсулювання гранульованих добрив плівкою.

\section{Інформація про авторів:}

Нагурський Олег Антонович, д-р техн. наук, професор, завідувач кафедри цивільної безпеки. Email: o_nagurskyy@ukr.net; https://orcid.org/0000-0002-5549-5296

Тимчук Іван Степанович, канд. с.-г. наук, асистент, кафедра екології та збалансованого природокористування. Email: i.s.tymchuk@gmail.com; https://orcid.org/0000-0001-9344-3035

Мальований Мирослав Степанович, д-р техн. наук, професор, завідувач кафедри екології та збалансованого природокористування. Email: myroslav.mal@gmail.com; https://orcid.org/0000-0002-5549-5296

Синельніков Сергій Дмитрович, провідний експерт. Email: Vk.pozh@gmail.com; https://orcid.org/0000-0002-6908-931X

Крилова Галина Василівна, аспірант, кафедра цивільної безпеки. Email: galusa0000@ukr.net; https://orcid.org/0000-0002-4039-3297

Цитування за Дсту: Нагурський О. А., Тимчук І. С., Мальований М. С., Синельніков С. Д., Крилова Г. В. Технологічні особливості капсулювання гранульованих добрив плівкою на основі модифікованого ПЕТФ. Науковий вісник НлТУ України. 2020, т. 30, № 2. C. 77-82.

Citation APA: Nagurskyi, O. A., Tymchuk, I. S., Malovanyy, M. S., Sinelnikov, S. D., \& Krylova, G. V. (2020). Technological aspects of granular fertilizers encapsulation with a film based on modified PET. Scientific Bulletin of UNFU, 30(2), 77-82. https://doi.org/10.36930/40300214 
Предмет дослідження - методи і засоби капсулювання гранульованих добрив плівкою на основі модифікованого ПЕТФ, що дасть змогу отримати гранульовані добрива із прогнозованими характеристиками.

Мета дослідження - визначити температуру, напір, швидкість зріджувального повітря та інтенсивність подачі плівкоутворювача у шар мінеральних добрив.

Для досягнення поставленої мети було сформовано та вирішено такі основні завдання дослідження:

- розробити теоретичниц метод визначення швидкості повітря в апараті псевдозрідженого типу для забезпечення потрібного гідродинамічного режиму;

- провести експериментальні дослідження тепло- та масообміну процесу капсулювання гранульованої аміачної селітри та нітроамофоски;

- визначити числові значення коефіцієнтів тепловіддачі $\alpha$ та коефіцієнтів масовіддачі $\beta$, які дали б змогу встановити витрату плівкоутворювача;

- за розрахованими технологічними параметрами отримати капсульовані плівкою гранульовані добрива із прогнозованими характеристиками.

Наукова новизна результатів дослідження полягає в тому, що вперше розроблено теоретичний метод визначення швидкості повітря в апараті псевдозрідженого типу для забезпечення потрібного гідродинамічного режиму тепло- та масообміну процесу капсулювання гранульованої аміачної селітри та нітроамофоски.

Практична значущість отриманих результатів свідчать про те, що визначено числові значення коефіцієнтів тепловіддачі $\alpha$ та коефіцієнтів масовіддачі $\beta$, які дали змогу встановити витрату плівкоутворювача та отримані капсульовані плівкою на основі модифікованого ПЕТФ гранульовані добрива із прогнозованими характеристиками.

Матеріали і методи дослідження. Для досліджень використовували два типи гранульованих синтетичних добрив: нітроамофоску - висококонцентроване комплексне універсальне азотно-фосфорно-калійне добриво; нітрат амонію (аміачна селітра) - амонійнонітратне добриво. Ці типи добрив використовують у сільськогосподарському виробництві у будь-яких грунтово-кліматичних зонах для основного, передпосівного підживлення різних культур [5, 15]. Для уникнення забруднення грунту мікропластиком, який може утворюватися у вигляді фрагментів використаної оболонки, до плівкоутворювача додавали гідролізний лігнін вологістю 45 \% (мас). Гідролізний лігнін є природним полісахаридом, який підвищує здатність полімеру до біодеструкції, є побічним продуктом перероблення деревини на паперово-целюлозному виробництві. Як основу плівкоутворювача використовували відходи поліетилентерефталату, які пройшли первинну переробку на спеціалізованому підприємстві. Для покращення розчинності та здатності до деструкції відходи ПЕТФ модифікували за методикою, описаною у роботі [11]. Для приготування розчину, модифікованого ПЕТФ, використовували етилацетат. У процесі капсулювання проводили опудрювання гранул меленим цеолітом. Цеоліт $є$ екологічно чистий сорбент, який використовують у сільськогосподарському виробництві для покращення властивостей грунту [7].

Дослідження теплообміну здійснювали за встановлених гідродинамічних умов процесу капсулювання, в установці, схему якої зображено на рис. 1 [12].

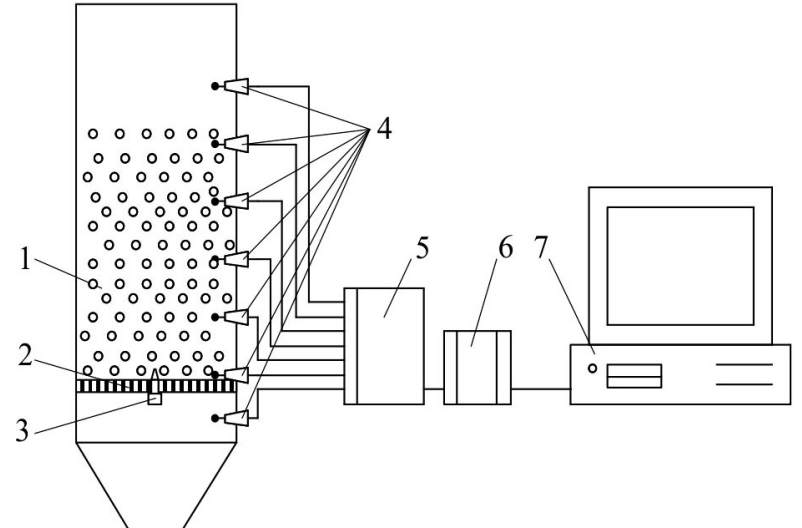

Рис. 1. Установка для дослідження теплообміну процесу капсулювання у псевдозрідженому стані: 1) циліндричний апарат ПШ; 2) газорозподільна решітка; 3) пневматична форсунка;

4) термопари; 5) інтелектуальний перетворювач ПВІ-0298;

6) перетворювач RS-232; 7) ПК

Для визначення температурних характеристик процесу залежно від висоти шару використовували 7-канальний інтелектуальний перетворювач ПВІ-0298, який дає змогу одночасно фіксувати температуру в семи точках з виводом інформації на ПК. Границя допустимої основної зведеної похибки перетворювача $\pm 0,25 \%$, час опитування всіх каналів не більше 3,5 с.

Розчинність капсульованих добрив досліджували кондуктометричним методом за методикою згідно з вимогами Європейської норми EN 13266:2001 [2].

Аналіз літературних джерел. Питанням розроблення технологій та апаратурного оформлення процесу капсулювання мінеральних добрив досліджено у багатьох наукових працях. У вітчизняній та зарубіжній літературі детально наведено результати гідродинаміки, тепло- та масообміну та динаміки нанесення плівкових покрить на тверді дисперсні матеріали $[12,13]$. Узагальнення цих чисельних праць показує, що визначальним у розробленні ефективних технологій капсулювання є фізико-хімічні властивості речовин твердої фази, у нашому випадку - гранульованих мінеральних добрив і плівкоутворювача. Тому для визначення основних технологічних параметрів процесу капсулювання необхідним є проведення експериментів із об'єктами досліджень.

Результати дослідження та їх обговорення. Капсулювання гранульованих добрив полягає у нанесенні на їх поверхню полімерної оболонки методом напилення рідкого плівкоутворювача на шар частинок. Для забезпечення якісного покриття частинки у шарі повинні постійно перемішуватися. У технологіях капсулювання твердих дисперсних матеріалів, зазвичай, використовують апарати трьох типів, які здатні забезпечити необхідний режим руху частинок: тарілчасті, барабанні та псевдозрідженного стану [12]. Під час капсулювання відбувається складний тепломасообмін між твердою фазою (поверхня частинок), рідиною (плівкоутворювач) і повітрям. На рис. 2 зображено схему такої взаємодії на прикладі одиночної частинки.

Потік нагрітого повітря $I$ контактує із твердою частинкою III, на поверхні якої міститься розчин плівкоутворювача. Унаслідок цього відбувається процес теплопередачі від газового середовища до поверхні твердої фази, який характеризується коефіцієнтом тепловіддачі $\alpha$. 


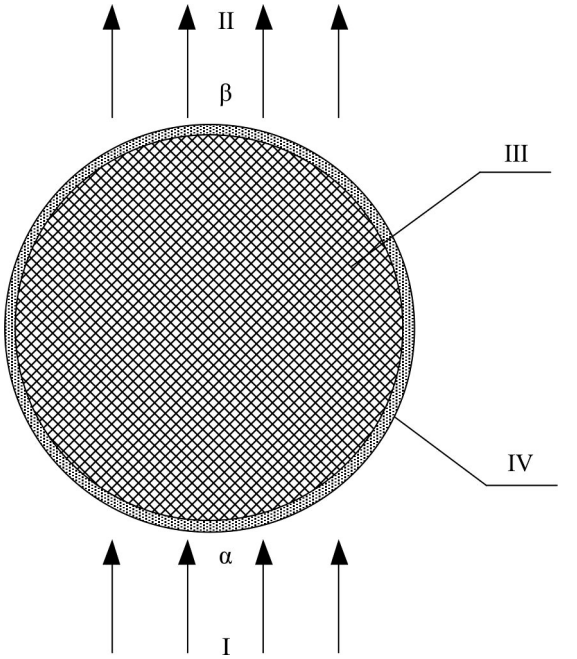

Рис. 2. Схема тепломасообміну у системі тверде тіло - рідина газ під час капсулювання: I - потік повітря, яке підводить тепло; II - потік повітря, яке відводить пари розчинника; III - тверда частинка; IV - розчин плівкоутворювача

Підведена теплова енергія витрачається на випаровування розчинника 3 поверхні частинки із інтенсивністю, яка характеризується коефіцієнтом масовіддачі $\beta$. Наведені у науковій літературі результати досліджень тепломасообміну під час капсулювання дисперсних матеріалів вказують, що обидва процеси належать до конвективних $[3,12]$. Вони характеризуються залежністю густини потоку тепла і маси, відповідно, до і від поверхні матеріалу, різниці температур або концентрацій. Визначальним впив на величини цих коефіцієнтів має інтенсивність омивання частинок повітряним потоком, яка характеризується його швидкістю і оцінюється числом Рейнольдса $R e$. У тарілчастих та барабанних апаратах потік повітря використовується лише для підведення тепла до поверхні частинок і відведення пари розчинника. В апараті псевдозрідженного стану повітря, окрім згаданих функцій, використовується для створення відповідного режиму руху частинок матеріалу. Під час капсулювання між частинками твердого матеріалу, на поверхні яких міститься розчин плівкоутворювача, спостерігається збільшення сил злипання. Це може призвести до утворення агломератів злиплих частинок $\mathrm{i}$, як наслідок, різкого погіршення якості кінцевого продукту. Для уникнення такого явища частинкам матеріалу потрібно надати відповідної кінетичної енергії, що практично реалізувати можливо в апараті псевдозрідженого стану. Для проведення експериментальних досліджень використовували апарат циліндричного типу періодичної дії. Такі апарати $є$ ефективними під час капсулювання матеріалів, схильних до злипання. Рухаючись усім перерізом апарата 3 постійною швидкістю повітря сприяє більш активній поведінці частинок, запобігаючи їх злипанню [12]. Відповідно, визначальним технологічним параметром процесу капсулювання $\epsilon$ швидкість повітря, за якої шар твердого матеріалу буде перебувати у стані стійкого псевдозвідження. Мінімальне ії значення $w_{k p}(\mathrm{~m} / \mathrm{c})$, за якої шар матеріалу переходить у псевдозріджений стан, визначається за допомогою таких критеріальних залежностей:

$$
R \mathrm{e}_{\mathrm{kp}}=\frac{w_{\mathrm{kp}} d}{v_{\mathrm{c}}}, R \mathrm{e}_{\mathrm{kp}}=\frac{A r}{1400+5,22 \sqrt{A r}}, A r=\frac{d^{3} \rho_{u} g}{v_{c}^{2} \rho_{c}},
$$

де: $d$ - діаметр частинки, м; $v_{c}$ - кінематичний коефіцієнт в'язкості повітря, $\mathrm{M}^{2} / \mathrm{c} ; \rho_{c}-$ густина повітря за умов процесу, кг $/ \mathrm{M}^{3} ; \rho_{4}-$ густина матеріалу частинки, $\kappa \Gamma / \mathrm{M}^{3}$.

Дійсне значення швидкості повітря є більшим за мінімальне на величину коефіцієнта псевдозрідження $k_{n з}$. Для забезпечення стійкої роботи апарату значення $k_{n з}$ приймаємо рівним 2. Унаслідок виконаних розрахунків отримано такі швидкості повітря (м/с): аміачна селітра $w_{a c}=5,6$; нітроамофоски $w_{\text {наф }}=6,1$.

Визначення коефіцієнтів теплообміну між теплоносієм (повітрям) та поверхнею частинок проводили за температурними показниками процесу. Температура проведення процесу капсулювання обмежується температурою кипіння розчинника та здатністю добрив до термічного розкладу. Беручи це до уваги, початкова температура повітря на вході в апарат дорівнювала $70{ }^{\circ} \mathrm{C}$. Маса шару мінеральних добрив становила у двох випадках 0,25 кг. Отримані експериментальні залежності наведено на рис. 3.

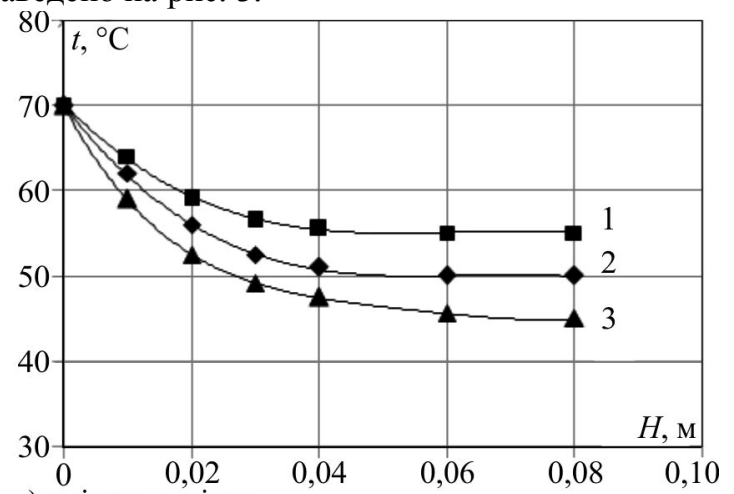

a) аміачна селітра

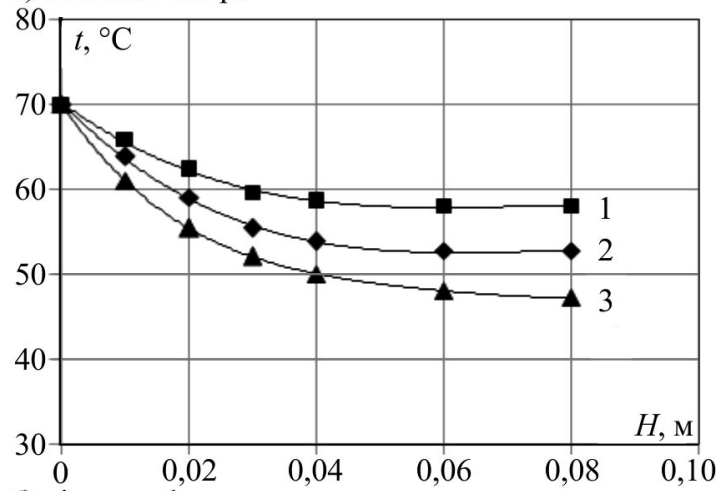

б) нітроамофоски

Рис. 3. Розподіл температури повітря з висотою шару гранульованих мінеральних добрив у процесі капсулювання за різної витрати плівкоутворювача (кг/с): $1-1 \cdot 10^{-4} ; 2-3 \cdot 10^{-4} ; 3-5 \cdot 10^{-4}$

Значення коефіцієнта тепловіддачі $\alpha$ від повітря до поверхні частинки визначали з використанням рівняння [12]

де:

$$
\begin{gathered}
\ln \frac{t-t_{\mathrm{MT}}}{\mathrm{t}_{\mathrm{n}}-t_{\mathrm{MT}}}=-\frac{\chi}{V_{c} \rho_{c} c} h, \\
\chi=\frac{\alpha 6 M(1-\varepsilon)}{\rho_{s} d H_{0}\left(1-\varepsilon_{0}\right)} ;
\end{gathered}
$$

$V_{c}$ - витрата повітря, ${ }^{3} / \mathrm{c} ; c$ - теплоємність повітря, Дж/(кгК); $t_{n}$ - температура повітря на вході в апарат, К; $r$ - питома теплота пароутворення розчинника, Дж/кг; $M$ - маса гранул мінерального добрива, кг; $\rho_{s}$ - густина матеріалу частинок, кг $/ \mathrm{M}^{3} ; H_{0}$ - висота шару матеріалу у нерухомому стані, м. $t_{m m}$ - температура мокрого термометра, К; $t$ - температура повітря по висоті шару, К; $\varepsilon_{0}-$ пористість матеріалу у нерухомому стані; $\varepsilon$ - порис- 
тість матеріалу у стані псевдозрідження; $h$ - рухома висота шару матеріалу, м.

Для цього будували графічні залежності $\ln \left[\left(t-t_{\text {мm }}\right) /\right.$ $\left.\left(t_{n}-t_{\text {мm }}\right)\right]$ від $h$ (рис. 4$)$.
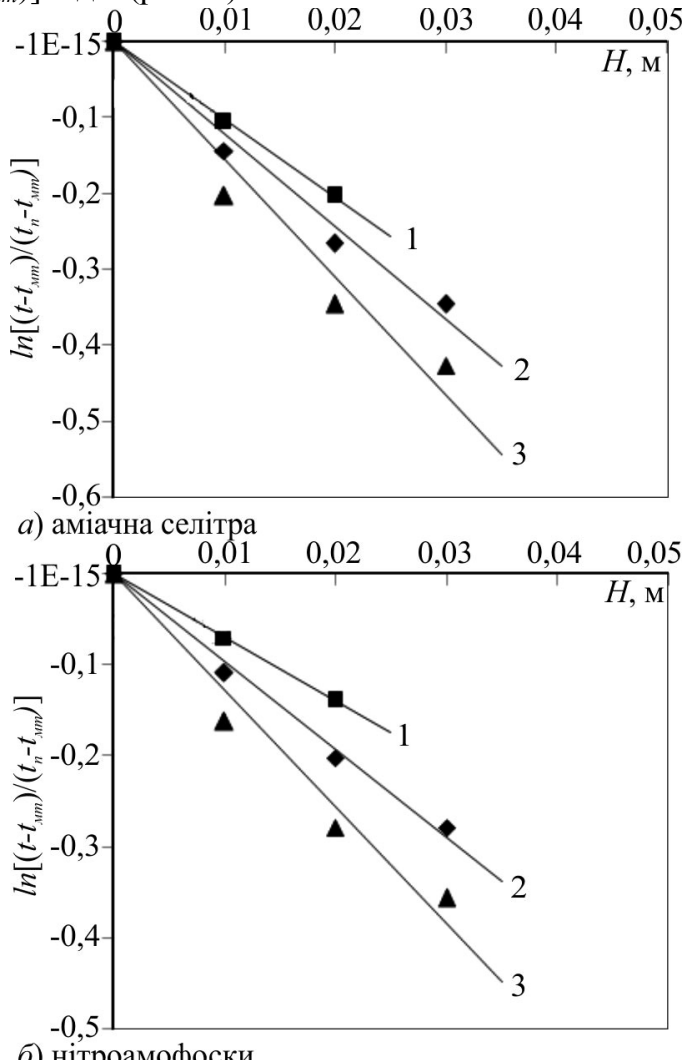

б) нітроамофоски

Рис. 4. Графічні залежності визначення значень коефіцієнта тепловіддачі від повітря до поверхні частинок гранульованих мінеральних добрив у процесі капсулювання за різної витрати плівкоутворювача (кг/с): $1-1 \cdot 10^{-4}, 2-3 \cdot 10^{-4}, 3-5 \cdot 10^{-4}$

У наведених залежностях тангенс кута нахилу прямої дорівнює $-\chi /\left(V_{c} \rho c\right)$, для визначення якого вибирали прямолінійну ділянку експериментальної кривої. Ця ділянка характеризує параметри шару матеріалу безпосередньо біля газорозподільної решітки та розпилювального пристрою і відповідає зоні максимального зрошення поверхні частинок. Використовуючи рівняння (3), визначаємо значення коефіцієнтів тепловіддачі від повітря до поверхні частинок (табл. 1).

Табл. 1. Значення коефіціснтів тепловіддачі $\alpha$ під час

капсулювання гранульованих мінеральних добрив

\begin{tabular}{|c|c|c|c|}
\hline Матеріал & $\begin{array}{l}\text { Витрата плівкоут- } \\
\text { ворювача, } 10^{4} \text { кг } / \mathrm{c}\end{array}$ & $\begin{array}{l}\text { Коефіц } \\
\text { віддачі }\end{array}$ & гепло- \\
\hline \multirow{3}{*}{ Аміачна селітра } & 1,0 & 134,8 & \multirow{3}{*}{135,7} \\
\hline & 3,0 & 135,4 & \\
\hline & 5,0 & 136,9 & \\
\hline \multirow{3}{*}{ Нітроамофоска } & 1,0 & 117,7 & \multirow{3}{*}{118,3} \\
\hline & 3,0 & 118,1 & \\
\hline & 5,0 & 119,2 & \\
\hline
\end{tabular}

Визначення швидкості випаровування $W$ (кг/с) розчинника із поверхні частинки мінерального добрива дасть змогу визначати інтенсивність зрошення шару матеріалу плівкоутворювальним розчином. Коефіцієнт масовіддачі $\beta$ (м/с) можна визначити із такого кінетичного рівняння [12]:

$$
W=\beta \cdot F\left(C_{\text {нас }}-C\right),
$$

де: $C_{\text {нас }}, C$ - концентрація пари розчинника у повітрі, відповідно, у стані насичення і робоча, кг $/ \mathrm{M}^{3} ; F$ - площа поверхні масообміну, ${ }^{2}$.

На практиці капсулювання дисперсних матеріалів у стані псевдозрідження здійснюється за умов, коли у масообміні одночасно бере участь лише частина поверхні матеріалу. Оцінити площу поверхні гранульованих добрив, яка бере участь у масообміні, можна опосередковано на підставі температурної кривої процесу капсулювання, отриманої експериментальним шляхом. Висота шару матеріалу, де практично завершився тепло масообмін, відповідає ділянці температурної кривої, де значення температури повітря залишаються незмінними. Для розрахунку коефіцієнтів масовіддачі $\beta$ використовували прямолінійну ділянку експериментальної кривої, як і у випадку визначення $\alpha$. Приймаємо, що на цій висоті шару у тепломасообміні бере участь уся поверхня частинок гранульованих добрив. Маса випареного розчинника на відповідній висоті шару $W_{h}$ (кг/с) пропорційна кількості затраченої теплоти:

$$
W_{h}=\frac{G_{c} \cdot c\left(t_{n}-t_{h}\right)}{r},
$$

де: $t_{h}$ - температура повітря на певній висоті шару, ${ }^{\circ} \mathrm{C}$; $r$ - питома теплота пароутворення розчинника, Дж/кг; $c$ - теплоємність повітря, Дж/кгК; $G_{c}-$ витрата повітря, кг $/ \mathrm{c}$.

За рівнянням тепловіддачі [9] отримаємо вираз:

$$
Q=\alpha \cdot F\left(t_{n}-t_{k}\right)
$$

розраховуємо площу поверхні частинок $F$, яка бере участь у тепломасообміні. Плівкоутворювальний розчин складався із таких компонентів: етилацетат $87 \%$ (мас), модифікований ПЕТФ $10 \%$ (мас), гідролізний лігнін $3 \%$ (мас). Відповідно, з урахуванням вмісту розчинника у плівкоутворювачі визначаємо величини коефіцієнтів масообміну, значення яких для досліджуваних гранульованих мінеральних добрив наведено у табл. 2. Числові значення коефіцієнтів тепловіддачі (див. табл. 1) і масовіддачі (див. табл. 2) корелюються із результатами інших авторів, отриманих для дисперсних матеріалів [1,3].

\begin{tabular}{|c|c|c|c|c|}
\hline Матеріал & $\begin{array}{l}\text { Витрата плівкоут- } \\
\text { ворювача, } 10^{4} \text { кг } / \mathrm{c}\end{array}$ & $\begin{array}{c}\text { Кількість випа- } \\
\text { реного розчин- } \\
\text { ника, } 10^{4} \text { кг } / \mathrm{c}\end{array}$ & $\begin{array}{r}\text { Коеф } \\
\text { масов } \\
\mathbf{M} \\
\end{array}$ & $\begin{array}{l}\text { цієнт } \\
\text { ддачі, } \\
\text { с }\end{array}$ \\
\hline \multirow{3}{*}{$\begin{array}{c}\text { Аміачна } \\
\text { селітра }\end{array}$} & 1,0 & 0,87 & 0,246 & \multirow{3}{*}{0,251} \\
\hline & 3,0 & 2,61 & 0,252 & \\
\hline & 5,0 & 4,35 & 0,256 & \\
\hline \multirow{3}{*}{$\begin{array}{c}\text { Нітроамо- } \\
\text { фоска }\end{array}$} & 1,0 & 0,87 & 0,195 & \multirow{3}{*}{0,198} \\
\hline & 3,0 & 2,61 & 0,197 & \\
\hline & 5,0 & 4,35 & 0,201 & \\
\hline
\end{tabular}

Табл. 2. Значення коефіцієнтів масовіддачі $\beta$ під час капсулювання гранульованих мінеральних добрив

На підставі отриманих коефіцієнтів масовіддачі розраховували максимальну витрату плівкоутворювача $P_{\max }\left(10^{4}\right.$ кг/с·кг добрив): аміачна селітра - 20,512, нітроамофоски - 22,857. На практиці використовувати максимальні значення витрати плівкоутворювача не доцільно. Для отримання якісного покриття приймаємо витрату плівкоутворювача 50 \% від максимальної. Відповідно отримуємо $\left(10^{4} \mathrm{\kappa г} / \mathrm{c} \cdot \kappa г\right.$ добрив): аміачна селітра $P_{A C}=10,25, P_{H A \Phi}=11,43$. У разі використання плівкоутворювачів із відмінною від досліджуваної пропорції компонентів інтенсивність процесу капсулювання мож- 
ливо розрахувати на підставі отриманих коефіцієнтів масовіддачі.

За отриманими технологічними параметрами здійснювали капсулювання гранульованих добрив (аміачної селітри та нітроамофоски) в апараті циліндричного типу періодичної дії. Величина покриття становила 10 i $20 \%$ від маси добрив, що відповідає таким середнім товщинам плівки на поверхні частинок $\left(10^{5} \mathrm{M}\right)$ : аміачна селітра -5,74 і 11,48; нітроамофоски - 5,23 і 10,46. Властивості отриманих добрив перевіряли експериментально. Результати досліджень у графічному вигляді наведено на рис. 5.

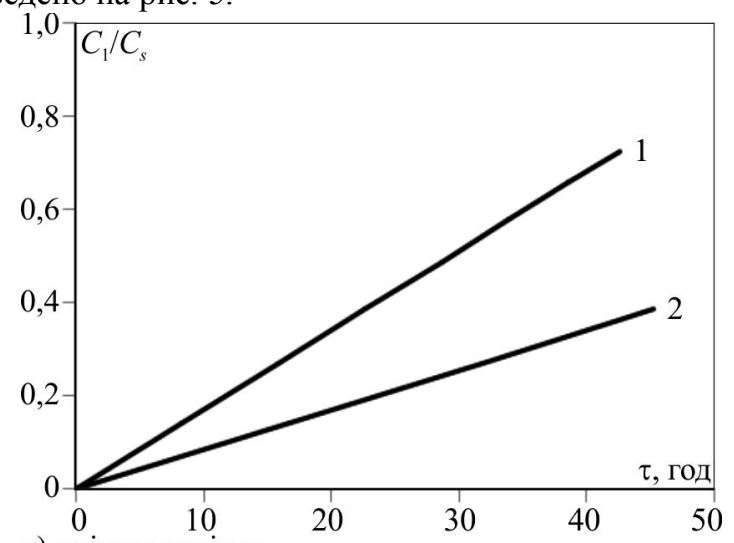

a) аміачна селітра

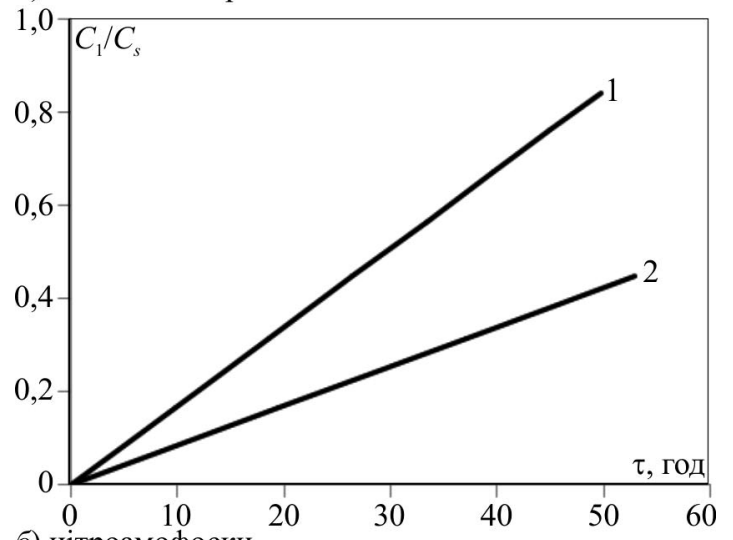

б) нітроамофоски

Рис. 5. Кінетика розчинення капсульованих добрив, покритих оболонкою на основі модифікованого ПЕТФ різної товщини (\% мас): $1-10 \% ; 2-20 \%$

Отримані результати (див. рис. 4) вказують, що кінетичні криві розчинення мають прогнозований характер, процес проходить плавно без різких спадів чи підйомів. Це слугує доказом рівномірного, якісного покриття, яке дає змогу отримувати мінеральні добрива подовженої дії із необхідним часом вивільнення.

Висновки. Теоретичним методом визначено швидкість повітря в апараті псевдозрідженого типу для забезпечення потрібного гідродинамічного режиму. Проведено експериментальні дослідження тепло- та масообміну процесу капсулювання гранульованої аміачної селітри та нітроамофоски. Визначено числові значення коефіцієнтів тепловіддачі $\alpha$ та коефіцієнтів масовіддачі $\beta$, які дали змогу встановити витрату плівкоутворювача. За розрахованими технологічними параметрами отримані капсульовані плівкою на основі модифікованого ПЕТФ гранульовані добрива із прогнозованими характеристиками.

\section{References}

1. Atamaniuk, V. M., \& Humnytskyi, Ya. M. (2013). Naukovi osnovy filtratsiinoho sushinnia dyspersnykh materialiv: monohrafiia. Lviv: Vydavnytstvo Natsionalnoho universytetu "Lvivska politekhnika", 276 p. [In Ukrainian].

2. DSTU EN 13266. (2017). Dobryva upovilnenoi dii. Vyznachennia dii pozhyvnykh rechovyn. Metod dlia pokrytykh dobryv (EN 13266:2001, IDT) . [In Ukrainian].

3. Flisiuk, E. V. (2004). Teplomassoobmen v protcesse naneseniia pokrytiia na tabletki v psevdoozhizhennom sloe. Khimiko-farmatcevticheskii zhurnal, 38(2), 67-68. [In Russian].

4. Hurets, L. L., Vakal, V. S., Vakal, S. V., \& Tsapko, Yu. L. (2018). Otsenka jekolohycheskoho jeffekta pry prymenenyy kapsulyrovannykh azotnykh udobrenyi. Ekolohichna bezpeka, 1(25), 61-68. https://doi.org/10.30929/2073-5057.2018.1.61-68

5. Kraievskyi, O. O., Osipov, V. A., \& Kraievskyi, O. I. (2013). Ekoloho-ekonomichna efektyvnist vykorystannia hranulovanykh azotnykh dobryv z orhanichnymy domishkamy. Visnyk Sumskoho derzhavnoho universytetu. Ser.: Ekonomika, 2, 20-23. [In Ukrainian].

6. Lisniak, A., Vilsek, Y., \& Torma, S. (2017). Ahroekoloichnyi efekt vykorystannia povilnorozchynnykh kapsulovanykh mineralnykh dobryv v lisovomu ta silskomu hospodarstvi. Visnyk Kharkivskoho natsionalnoho universytetu imeni V. N. Karazina. Seriia "Ekolohiia", 17, 29-35. https://doi.org/10.26565/19924259-2017-17-03

7. Malovanyi, M. S., \& Petrushka, I. M. (2012). Ochyshchennia stichnykh vod pryrodnymy dyspersnymy sorbentamy. Lviv, 180 p. [In Ukrainian].

8. Nagurskii, O. A., Malovanii, M. S., Sinelnikov, S. D., \& Vashhuk, V. V. (2015). Zastosuvannia polimernikh vidkhodiv dlia kapsuliuvannia mineralnikh dobriv. Scientific Bulletin of UNFU, 25(8) 139-145. https://doi.org/10.15421/40250823

9. Nagursky, O., \& Gumnitsky, Ya. (2015). Mass exchange of dispersed materials encapsulating in quasi-liquefaction state. Chemistry \& Chemical Technology, 9(3), 333-336. https://doi.org/10.23939/chcht09.03.333

10. Nagursky, O., Malovanyy, M., Sinelnikov, S., Tymchuk, I., \& Krylova, G. (2020). Studying the properties of granulated anp fertilizer encapsulated with pet-based shell. Environmental problems, 5(1), 35-38. https://doi.org/10.23939/ep2020.01.035

11. Nagursky, O., Malovanyy, M., Synelnikov, S., \& Vahchuk, V. (2016). Prospects of using pet waste for environmentally friendly mineral fertilizers. Environmental problems, 1(1), 19-21.

12. Nahurskyi, O. A. (2012). Zakonomirnosti kapsuliuvannia rechovyn u stani psevdozridzhennia ta yikh dyfuziinoho vyvilnennia. Lviv, 188 p. [In Ukrainian].

13. Ovchinnikov, L. N., \& Lipin, A. G. (2011). Kapsulirovanie mineralnykh udobrenii vo vzveshennom sloe. Ivanovo, $140 \mathrm{p}$. [In Russian].

14. Pirogovskaia, G. V. (2000). Medlennodeistvuiushhie udobreniia. Minsk, 291 p. [In Russian].

15. Pryimak, V. V. (2018). Zastosuvannia mineralnykh dobryv v ahroekosystemakh pivdnia Ukrainy. Yntellektualnyi potentsyal XXI veka 2018. Odessa, 94-97. https://doi.org/10.21893/978-6177414-40-6.0

16. Synelnikov, S., Soloviy, K., Malovanyy, M., Tymchuk, I., \& Nahurskyy, O. (2019). Improvement of environmental safety of agricultural systems as a result of encapsulated mineral fertilizers implementation. Environmental problems, 4(4), 222-228. https://doi.org/10.23939/ep2019.04.222

17. Zukerman, Yigal, G. (2004). How to boost nitrogen use efficiency. International journal of fertility and menopausal studies, 400, 147-151. [In Ukrainian]. 


\section{TECHNOLOGICAL ASPECTS OF GRANULAR FERTILIZERS ENCAPSULATION WITH A FILM BASED ON MODIFIED PET}

Improvement of the technology of obtaining encapsulated mineral fertilizers which are used to increase the efficiency of nutrients assimilation by plants under conditions of their dosage to the root system is a promising method of solving environmental pollution by residual agrochemicals. The parameters of heat and mass transfer during encapsulation were determined according to the temperature indicators of the process in the apparatus of a pseudo-liquefied state of cylindrical type periodic action. The temperature dependence of the fluidized air with the height of the granular fertilizer layer was fixed at seven points, with information output to the computer, with the help of vertically positioned thermocouples connected to a seven-channel smart converter. The main technological parameters of the process of encapsulation in the state of pseudo-liquefaction are the speed and temperature of the air and the flow rate of the film-forming solution, which are determined by the physical and chemical properties of fertilizers and film-forming agent. The air velocity in the apparatus necessary to ensure a stable state of pseudo-liquefaction is calculated theoretically, which for ammonium nitrate is $5,6 \mathrm{~m} / \mathrm{s}$, nitroamophos $-6,1 \mathrm{~m} / \mathrm{s}$. The air temperature at the inlet of the apparatus was limited by the boiling point of ethyl acetate and the thermal stability of the fertilizers and was equal to $70{ }^{\circ} \mathrm{C}$. Under the conditions of the established air velocity and temperature, the temperature dependence with the height of the fertilizer layer during encapsulation of a film-forming solution consisting of ethyl acetate $87 \%$ (wt), modified PETF $10 \%$ (wt), hydrolysis lignin $3 \%$ (wt) was experimentally studied. The graphical method of the slope of the temperature curves established the values of the coefficients of heat transfer $\alpha$ during the encapsulation of ammonium nitrate $135,7 \mathrm{~W} /\left(\mathrm{m}^{2} \mathrm{~K}\right)$ and nitroamophos $118,3 \mathrm{~W} /\left(\mathrm{m}^{2} \mathrm{~K}\right)$. According to the temperature characteristics of the fertilizer layer, the coefficients of mass transfer $\beta$ during encapsulation of ammonium nitrate $0,251 \mathrm{~m} / \mathrm{s}$ and nitroamophos $0,198 \mathrm{~m} / \mathrm{s}$ were determined. Based on the obtained mass transfer coefficients, the maximum flow rate of the $P_{\max }$ film maker $\left(10^{4} \mathrm{~kg} / \mathrm{s} \cdot \mathrm{kg}\right.$ of fertilizer $)$ was established: ammonium nitrate $-20,512$, nitroamophos $-22,857$. Ammonium nitrate and nitroamophos were encapsulated and the experimental tests on fertilizers encapsulation were conducted according to the requirements of European standard EN 13266: 2001. The analysis of kinetic dependences showed the possibility of production of prolonged-action mineral fertilizers using wastes of polyethylene terephthalate, hydrolysis lignin under determined technological conditions in the apparatus of the pseudo-liquefied state.

Keywords: encapsulation; PET waste; heat exchange; mass exchange; mineral fertilizers. 